\title{
Recent Developments in Japan's International Peace Cooperation Under the Second Abe Government 2012-2020
}

\section{Reforming Japanese Security Policy, 2013-2015}

\subsection{The National Security Strategy and the Other Significant Changes}

Shinzo Abe, the president of the ruling LDP, was first inaugurated as Japan's prime minister in 2006, succeeding Prime Minister Junichiro Koizumi. However, due to health problems, Abe was forced to resign just a year later. Following Abe's 2007 resignation, the LDP government experienced political instability and was soon replaced by the DPJ in 2009. The DPJ government also faced internal challenges and weak public support, which led to Abe's second premiership at the end of 2012. After his return to power, Prime Minister Abe enjoyed a firm political basis and remained in power for nearly eight years, until September 2020. Domestic political stability provided Abe with considerable latitude to push through ambitious (as well as controversial) reforms in Japan's security policy.

During his first term, Abe had already attempted to reconsider Japan's security policy by commissioning the first Security Experts Panel in April 2007. However, he stepped down from power in September 2007 before the first panel submitted their outcome report in June 2008 (see Chap. 3). Soon after returning to power, Abe commissioned the second round of the Security Experts Panel in February 2013, resulting in the release of an updated version of the policy recommendations in May 2014. Abe's bold

(C) The Author(s) 2022

H. N. Fujishige et al., Japan's Peacekeeping at a Crossroads, Sustainable Development Goals Series, https://doi.org/10.1007/978-3-030-88509-0_4 
reform of Japan's security policy framework took place along the blueprint outlined by the Security Experts Panel's recommendations in 2008 and 2014.

We will present here the three major features of Abe's ambitious reforms of Japanese security policy. First, as soon as he returned to power, Abe began to formulate a comprehensive national security policy framework. This was published a year later in December 2013 as the "National Security Strategy" (MoFA, 2013). The National Security Strategy presents a series of fundamental principles, not only narrowly for defense policy but also more comprehensively for Japan's security policy. It was the first time that the GoJ had articulated such explicit principles for the entire vision of its security policy, uniting various issue domains in both military and nonmilitary affairs into a single strategic space of security policy. ${ }^{1}$ Almost concurrently, the National Security Council (NSC), which is the ministerial organization on security affairs, and the National Security Secretariat (NSS), the administrative body to support the NSC, were established.

At the core of the set of policies presented by the National Security Strategy was an idea called "Proactive Contribution to Peace," which is based on the principle of international cooperation. This new concept offers an expansive understanding of Japan's security policy. Assuming that Japan's security policy is clearly connected with the stability of the Asia-Pacific region and, more broadly, with that of international society, the National Security Strategy declares its clear commitment to its alliance with the US, as well as with larger international security. By interpreting the concept of "security" in a comprehensive sense, rather than in the sense of narrow national defense, the National Security Strategy also clearly articulates an intent to combine military and nonmilitary measures. A similar catchphrase- "International Contribution"-was often heard in the first half of the 1990s, but this was more exclusively focused on Japan's contribution to multinational activities, such as the dispatch of the SDF to UNPKOs. In contrast, the 2013 version advocated a sweeping vision that encompassed national, regional, and international security. It emphasized alliance relations both with the US and with other friendly states within the multilateral framework. Moreover, it proposed to create close linkages between military tools and development aid in providing overseas assistance. Under the second Abe administration, Japan's peacekeeping policy would be situated within this grand design of expanded national security as a whole rather than in the narrow context of supporting the UN. 
To implement the extensive renovation of security policy laid out in the National Security Strategy, two key policy papers were revised: one for defense policy and the other for development aid. Concurrent with National Security Strategy adoption in December 2013, the National Defense Policy Guidelines (NDPG) (MoD, 2020), ${ }^{2}$ which had last been revised in 2010, was also updated to integrate defense policy into the allinclusive national security framework. Two years later, in February 2015, the Development Cooperation Policy Outline was also issued. Unlike the preceding document (The ODA Policy Outline, last revised in 2003; MoFA, 2015), ${ }^{3}$ which had narrowly focused on development issues, this new charter of 2015 aimed to incorporate development aid as a part of the national security policy framework.

This new policy goal expanded the scope of "Development Cooperation" from its narrow focus on socioeconomic aid to a more holistic vision that also covers political issues such as peacebuilding, governance, and human rights (MoFA, 2015). It also exhibited the intent to connect public financial resources and activities with those of various actors outside the government, namely UNPKOs, NGOs, and private businesses. These efforts confirmed Japan's motivation to pursue greater "integration," as typically seen in the promotion of the "All Japan" approach, combining the SDF's peacekeeping efforts (inter alia, the JEG's construction works) and Japan's ODA programs in order to provide direct assistance to the local population (see Chap. 3).

\subsection{Amending the Official Interpretation of the Right of Collective Defense}

After the National Security Strategy, Abe's next target was to create a legal force to guide the new grand vision of security policy. Although the comprehensive security policy reform package included amending the PKO Act, Abe mostly aimed to enhance the alliance partnership with the US. In those days, concerns were rising about the unstable strategic environment in the neighborhood, especially involving China and North Korea. The intensification of security threats in the neighborhood had made Japan keener to strengthen its alliance partnership with the US. Nevertheless, those efforts ran the political risk of being perceived by the anti-military opposition and the public as violating the constitutional ban on the exercise of collective defense rights (see Chap. 3). Since 1972, the GoJ had held this official position concerning collective self-defense rights: "Japan, 
as a sovereign nation, has an inherent right to collective defense under international law, but the restrictions imposed by Article 9 of the Constitution are such that the government cannot constituently exercise this right" (Sakata, 2013, p. 64, as cited in Mori, 2019, p. 4).

The Abe government changed the interpretation of the Constitution in July 2014 to permit the exercise of collective self-defense rights, albeit with some reservations $(\mathrm{MoD}, \mathrm{n} . \mathrm{d}$.). The activation of the collective selfdefense right considerably expanded the scope for broader IPC, especially with regard to the adoption of the International Peace Support Act, which will be further discussed later in this chapter.

\subsection{The Move Toward "Integration" Under the Second Abe Administration}

The second Abe administration also emphasized a move toward "integration" as expressed in the National Security Strategy and in the Development Cooperation Charter (Uesugi et al., 2021). The Abe government not only promoted the "All Japan" approach along these lines, but also intended to utilize the SDF's engineering capability, as expressed at the Leaders' Summit on Peacekeeping in New York, in both 2014 and 2015 (Cabinet Secretariat, 2015). Abe clearly expressed his will not only to dispatch the JEG to the field, but also to provide training for military engineers from African countries in order to facilitate the rapid deployment of peacekeepers. The JEG also took the initiative in 2015 of publishing the first-ever UNDPKO manual for its engineering forces sent to UNPKOs, which was updated in 2020. A large part of these efforts toward greater "integration," however, was set back by the JEG's abrupt withdrawal from South Sudan in 2017 (see Chap. 8). The GoJ, therefore, had to focus on activities other than its personnel deployment (see Chap. 9).

\subsection{The Impact of Peace and Security Legislation on Japan's Peacekeeping Policy}

In May 2015, Prime Minister Abe submitted the Peace and Security Legislation bills to the Diet to establish a legal foundation for his review of security policy from 2013 to 2014 . Abe's very ambitious intent to sweep away a whole set of long-standing agendas in security policy, however, raised suspicion and caution from the Japanese public, with accusations from remnants of the anti-military camp calling them the "war bills" (The 
Central Committee of JCP, 2015). However, just four months later, the Abe administration pushed the bills through the Diet rather easily, as the LDP-led ruling coalition occupied over two-thirds of the legislature. The Peace and Security Legislation was enacted in September 2015 and came into effect in March 2016.

The Peace and Security Legislation comprised ten legal amendments and one new law. As part of this wholesale legal renovation, the amended PKO Act and the new International Peace Support Act were most closely tied to Japan's peacekeeping and IPC-related policies. The following sections will examine their impacts in closer detail.

\section{Amendments to the PKO Act ${ }^{4}$}

\subsection{Overview of the 2015 Amendments}

The PKO Act had been previously amended twice, in 1998 and 2001, but these changes remained minimal and only within the scope of selfpreservation (see Chap. 3). Even after these revisions, a considerable gap remained between Japanese policy and the international trend of "robustness." To address these remaining problems, the PKO Act was amended a third time as a part of the Peace and Security Legislation in 2015.

Three important policy changes were made as a result of the third amendment to the PKO Act. First, the provisions on the use of weapons by the SDF peacekeepers were relatively relaxed by adding the "comingto-aid" duty, which is the JEG's very limited security role, mainly to protect Japanese nationals at a distant location and the "providing protection to the local population" (hereafter, "provision of protection") duty, which denotes the infantry's mission to protect the local population, properties, and so on. These are especially crucial in having expanded the permitted range of weapons use for the "execution of missions (nimmu-suiko)" purpose beyond the scope of self-preservation. ${ }^{5}$ This was the first time that the PKO Act had included the stipulations to authorize the use of weapons for "execution of missions" (for more details, see below). Moreover, the "joint defense of a camp" duty was added to expand the permitted range for the use of weapons within the category of self-preservation. Furthermore, the amendments to the PKO Act in 2015 also introduced the following new activities, namely the "internationally coordinated operations for peace and security," Security Sector Reform (SSR)-related 
activities, and the preventive deployment of the SDF before an armed conflict breaks out (see below for more details).

\subsection{Defining the "Use of Force" in the Japanese Legal Framework}

Before examining the details of newly added roles, it is necessary to scrutinize the definition of "use of force" in light of the constitutional framework. As we have seen so far, the Constitution clearly prohibits the use of force, and hence, the allowed range of activities for the SDF peacekeepers has been strictly constrained to avoid the use of force (see Chaps. 2 and 3 ). When the bill for the PKO Act was discussed at the Diet in September 1991, the GoJ clearly differentiated the "use of force" from the "use of weapons" allowed for the SDF peacekeepers in the PKO Act:

In general, the "use of force" in Paragraph 1, Article 9 of the Constitution denotes an act of fighting as part of an international armed conflict by [Japan's] physical and personnel organizations, while the "use of weapons" in Article 24 in the [PKO] bill is defined as the use of firearms, explosives, bladed weapons, and other machines, implements, and devices that are aimed to hurt or kill people or to destroy things as a means of armed fighting [...]. (GoJ, 1991)

This clarifies the details of "use of weapons," but the definition of "use of force" seems more abstract and somewhat unclear, especially concerning the meaning of "international armed conflict." Later, a more precise definition of "international armed conflict" was provided. In 2002, the GoJ defined "international armed conflict" as "a situation in which state or quasi-state organizations have a disagreement over a specific issue, stick to their own opposing positions and are not willing to concede [emphasis added]" (Koizumi, 2002).

Combined with the 1991 definition, mentioned above, this official definition in 2002 clarifies a very important point: that the SDF's use of weapons will be regarded as the "use of force" when they do so against a "state or quasi-state organization" as an adversary party. The term "state organization" can be straightforwardly understood as a political entity that is entitled to the status of a sovereign state. But what is a "quasi-state organization"? In 2003, Director-General of Defense (equivalent to the Minister of Defense $)^{6}$ Shigeru Ishiba (2003) articulated the concept of a 
quasi-state organization as an organization that fulfilled all or some of the three requirements of a state (territory, people, and political system) and could serve as an independent agent in an international armed conflict, albeit without international recognition as a formal sovereign state. According to him, the Taliban in Afghanistan exemplified a quasi-state organization, while a much smaller-sized group would not fall into this category. While acknowledging this as his own personal view, Ishiba also stated that it would be impossible to define exactly what a quasi-state organization would be, and the issue of whether an actor could be regarded as a quasi-state organization or not would depend on the interpretation of a given situation. In short, this meant that it was virtually left as a political decision to determine whether or not a situation would be regarded as the "use of force," leaving a risk of arbitrary use.

\subsection{Use of Weapons for "Self-Preservation" and "Execution of Missions"}

Next, let us examine the distinction between the use of weapons for "selfpreservation" and the "execution of missions" purposes. The differentiation is very confusing but the Director-General of the Cabinet Legislation Bureau, Yusuke Yokobatake (2015), articulated the differences as follows:

The use of force in Paragraph 1, Article 9 of the Constitution is $[\ldots]$ an international armed conflict by [Japan's] physical and personnel organizations or, specifically, the conduct of hostilities as part of an armed conflict generated between [or among] state or quasi-state organizations. [...] Article 9 of the Constitution allows our country to use force only to the minimum extent necessary under an unavoidable situation to defend our country. The use of force beyond this or for other [purposes] is not permitted. [...] [The GoJ] has decreed that even an adversary party is a state or quasi-state organization, the use of weapons for self-preservation as the natural right and the protection of armament and the other [equipment of the SDF] does not constitute the use of force, which is prohibited by the Constitution. [...] [The GoJ] has also decreed that [...] the use of weapons for "execution of missions" or for "coming-to-aid" duty would constitute the use of force if an adversary party is a state or quasi-state organization and this would generate a problem related to the Constitution.

In other words, if it is a case of self-preservation, then SDF personnel's use of weapons will not constitute the use of force (Nakatani, 2015); 
hence, the SDF peacekeepers are allowed to use weapons regardless of whether the adversary party is a state or a quasi-state organization. Put another way, SDF personnel are now automatically allowed to use weapons under this category because self-preservation has been recognized as a natural right that applies to all humanity.

In contrast, in the case of the "execution of missions" purpose, an SDF member is permitted to use weapons only when assigned a specific duty: either "provision of protection" or "coming-to-aid" duty. The use of weapons for "execution of missions" exceeds the range of self-preservation, but it would be permitted "only if a state or quasi-state organization does not appear [at the scene where the SDF personnel operate] as an adversary party" (Yokobatake, 2015). The GoJ thus excludes the (theoretical) possibility of confronting a state or quasi-state organization, or more essentially the use of force in an international armed conflict, in relation to the use of weapons for the "execution of missions" purpose.

Moreover, the GoJ expects that the "execution of missions" duty would accompany only the limited use of weapons for police-like activities, such as the rescue of Japanese nationals with consent from a host nation, even if the SDF personnel use arms beyond the "self-preservation" purpose (MoFA, 2014). This reasoning also aims to minimize the extent of the use of weapons even if it goes beyond the range of "self-preservation."

\subsection{The Revision to the Fifth of the Five Principles}

To avoid the danger of situations constituting the use of force, which is banned by the Constitution, SDF personnel would be assigned tasks for the "execution of missions" purpose, either for "provision of protection" or "coming-to-aid" duties, only when the absence of a state or quasi-state organization as an adversary party could be confirmed. For this purpose, the GoJ would assign these tasks to the SDF personnel only on the condition that consent for the conduct of the UNPKO as well as Japan's participation in such operations could be consistently maintained by the host nation as well as by other concerned parties (Nakatani, 2015). Furthermore, the GoJ will make a final decision on whether such consent and acceptance are constantly maintained based on the deliberation of the NSC.

Here lies the hypothetical premise that there will be no danger of the SDF peacekeepers being involved in an armed conflict if all warring parties, either state or quasi-state organizations, give consistent consent for the conduct of a UNPKO as well as for the SDF's deployment to the field. 
Along this line, the Abe administration inserted this requirement (the existence of consistent consent from major concerned parties regarding the deployment of a UNPKO as well as the participation of a Japanese contingent in the mission) as the fifth of the revised version of the Five Principles as a prerequisite to allow the SDF to use weapons for the "execution of missions," namely the "provision of protection" and "comingto-aid" duties (MoFA, 2014, 2016): The fifth item of the new Five Principles reads as follows:

The use of weapons shall be limited to the minimum necessity for the protection of the lives of personnel dispatched, in principle. When the consent for acceptance is deemed to be consistently maintained, the use of weapons in defense of the mission mandate is allowed in accordance with specific requirements [emphasis added]. (MoFA, n.d.)

It goes without saying that this stipulation was introduced to make sure that SDF personnel tasked with "execution of missions" would never be involved in an international armed conflict, avoiding the use of force against a state or quasi-state organization. Nonetheless, it is highly questionable whether such a premise can be maintained in the field. In an internal war, which represents the major type of armed conflict today, political will and power, as well as the chain of command, are often fragmented and changeable. Under such political and hierarchical instability, the level of consent to the presence of peacekeepers changes frequently. Hence, it could be even fictional to assume that such constant consent can be made in the circumstance where the cotemporary UNPKOs are being deployed. As a result, the addition of this stipulation entailed the risk of widening the gap between the Japanese national legal requirement and the reality of UNPKOs, as we would actually see in South Sudan (see Chaps. 1 and 8 ).

\subsection{Three Types of UNPKO for the Application of the New Five Principles}

With the 2015 amendment to the PKO Act, the categorization of three types of UNPKO was newly inserted into the application of the Five Principles (Table 4.1). The introduction of types (b) and (c) relatively loosened the requirement to fulfill the Five Principles, as it would suffice to satisfy only three (Principles 2,4 , and 5). ${ }^{8}$ In particular, type (b) was 
Table 4.1 Three types of UNPKO for the application of the new five principles

Three types of UNPKO, categorized in the revised PKO Act

Required

fulfillment of five

principles

(a) Operations conducted without partiality when consent exists among the warring parties concerning the cessation of cease-fire of an armed conflict and the consent from a host nation and

All of the warring parties concerning the acceptance of such operations

(b) Operations conducted with the consent of the host nation when an armed conflict has been concluded and warring parties have ceased to exist and the consent from a host nation and warring parties concerning the acceptance of such operations

(c) Operations conducted without partiality for the purpose of conflict prevention when an armed conflict has not yet occurred with the consent of the host nation concerning the acceptance of such operations principles need to be fulfilled

Principles 2, 4, and 5 need to be fulfilled

Principles 2, 4, and 5 need to be fulfilled

The 2015 PKO Act (2015, art. 3, i), Authors' creation

employed to endorse the contribution of the SDF to South Sudan (see Chap. 8).

\subsection{The Relaxation of Weapons Use Requirements: The "Provision of Protection" Duty}

Just like the PKF's main duties, the ban upon which had been lifted in 2001 , the "provision of protection" duty would be basically assigned to infantry troops that specialize in combat missions. In 2015, the "provision of protection" duty was added mainly because the "PKF main duties," which focused on the classic way of peacekeeping (e.g., truce monitoring and patrol), had already become outdated in the contemporary UNPKOs (see Chaps. 1 and 2). The GoJ defines the "provision of protection" duty as the task of providing security to the local population with "the use of weapons to the extent necessary to protect the lives, bodies, and properties of the local population, affected people and other populations requiring protection, or to repel obstructions to the execution of their duties" (Nakatani, 2015). The addition of the "provision of protection" duty intended to catch up with the recent trend of infantry roles in a UNPKO, such as robust peacekeeping for the purpose of PoC. Indeed, the 
purpose-providing protection to the locals—seems very similar to the PoC mission in the UNPKOs, which falls into the category of the "defense of the mandate" task (see Chap. 1). According to the GoJ, however, the concept of "execution of missions" differs from the notion of "defense of the mandate" in the UN standard: the former strictly excludes the possibility of using weapons against a state or quasi-state organization, in order to avoid the use of force, while the latter has no such restriction (Kishida, 2015a). For this reason, as mentioned above, the new Five Principles demand consistent consent from all concerned parties to avoid the possibility of a state or quasi-state organization existing as an adversary party in the field where the SDF peacekeepers operate.

In practice, it seems very unlikely that the GSDF infantry would be deployed for the "provision of protection" duty. This is not only because it could be highly dangerous and is deemed politically too risky for the GoJ, but also because, as we will see later, this task will require official consent from the Diet prior to dispatch, which could be very hard to obtain. Indeed, the Japanese infantry corps has still never been dispatched for peacekeeping missions, despite the removal of the "freeze" on the PKF's main duties in 2001. In sum, there exists only a slim chance that Japan's infantry will ever be assigned to "provision of protection" duty, at least for the foreseeable future.

\subsection{The Relaxation of Weapons Use Requivements: The "Coming-to-Aid" Duty}

The "coming-to-aid" duty denotes the task of coming to the aid of individuals related to the UNPKO (or other mission), other than the SDF personnel themselves in the same contingent, who are at a distant location where they are under attack or are facing imminent danger, in response to an urgent request for protection. As seen earlier (see Chap. 3), the amendment to the PKO Act in 2001 authorized the use of weapons under the "self-preservation" category to protect those other than the SDF personnel themselves if these people are at the same scene as the SDF members or are under their supervision. If these people are located at a distance from the SDF, according to the GoJ's interpretation, the logic of "selfpreservation" cannot be applied. For this reason, the "coming-to-aid" duty, as well as the "provision of protection" duty, would be deemed to fall under the "execution of missions" category. Unlike the "provision of protection" duty, however, the "coming-to-aid" duty does not require 
official consent from the Diet prior to dispatch because it is an emergency operation and needs prompt action. This makes the "coming-to-aid" duty more feasible than the "provision of protection" duty.

The "coming-to-aid" duty is basically assigned to an SDF unit other than the infantry corps-usually the JEG. The engineering corps, which is primarily assigned for the "coming-to-aid" duty, is categorized as combat support within the military. Their intended role is to assist the combatoriented forces, made up of infantry forces, by developing a conducive environment on the ground. In other words, the engineers are not particularly well-suited to direct combat-oriented duties, although they do have the basic fighting skills and necessary equipment to prepare for an emergency. An infantry force basically assumes a combat and securityrelated role; an engineering force may engage in these tasks, but only when infantry troops are not available.

Even when assigned to "coming-to-aid" duty, therefore, the JEG remains expected to primarily engage in construction and infrastructure development while preparing for the use of weapons in an emergency. In the meantime, security duties, especially the PoC mission, would basically be the responsibility of the infantry forces of a host nation and/or a UN mission. Nevertheless, if these infantries cannot provide security when UN-related or other personnel are in imminent danger, then the JEG empowered with the "coming-to-aid" duty would be allowed to use weapons to rescue them even if they are found in a remote location (Cabinet Secretariat et al., 2016). To do so, the JEG is permitted to use weapons beyond self-preservation, but only to the minimum extent required and as a temporary emergency measure.

In these cases, the JEG are directed to save those who are in need of protection when in an emergency, such as personnel of the UN, other international organizations, and NGOs, as well as any Japanese nationals with close relations to the relevant Japanese delegation (Ishikawa, 2015). ${ }^{9}$ A case fitting this description actually occurred in the former Zaire in 1994 and East Timor in 2002 (see Chaps. 3 and 6). In the meantime, the protection of the local population goes beyond the scope of "coming-toaid" duty. So far, there is only one precedent of an engineering unit ever being assigned a "coming-to-aid" duty during the period from December 2016 to May 2017: the UNMISS example. In practice, the JEG withdrew from the young African nation in 2017 before actually performing that "coming-to-aid" duty, which means that there is no empirical case in this category. We will examine this issue again in Chaps. 8 and 9. 


\subsection{Catching Up with "Robustness"?}

Seemingly, the Abe government added these two new tasks to the PKO Act in the 2015 amendment as a nod toward the trend of "robustness" in the UNPKOs and in line with previous expert recommendations. In fact, the inclusion of these two duties for the "execution of missions" purpose brought some formal changes to the PKO Act, in the sense that it now went beyond the previous focus on self-preservation. Nonetheless, it is highly doubtful to what extent the introduction of these new duties has actually reduced the gap in "robustness" between the Japanese legal system and global UNPKO trends.

The influence of policy recommendations by the IPC Panel in 2002 and the Security Experts Panel in 2008 and 2014 (see Chap. 3) was clearly behind the 2015 amendments to the PKO Act. These three expert committees all expressed serious concerns about the wide gap in "robustness" between Japan and the rest of the world, and strongly demanded that the GoJ follow the trends of UNPKOs. Their policy paper (2008) criticized the gap between Japan's position and the international standard as follows:

Japan applies standards that are far different from international standards on the use of weapons. Consequently, the SDF participating in UNPKOs has to act in accordance with standards that are different from those applied to the units of other countries, even though they are engaged in joint operations. This makes it difficult for the SDF to participate actively in UNPKOs [emphasis added]. ${ }^{10}$ (pp. 12-13)

The quotation above clearly illustrates high motivation on the part of Japanese experts, such as academics and former UN officials, to conform to the "international standard" (in "robustness") by seeking to maximize the size of its personnel contribution as much as possible. Bearing the common motivation of "catching up with the international trend," the three panels' reports, especially those published in 2008 and 2014, called for the addition of the "coming-to-aid" and "provision of protection" duties (Prime Minister of Japan and His Cabinet, 2002, para. 2-8; The Security Experts Panel, 2008, p. 13, 2014, pp. 37-38). For example, the 2008 report urged the inclusion of the "coming-to-aid" duty as follows:

[I]f the SDF does not come to the aid of units or personnel from other participating countries that are in danger and in need of help, solely because the SDF is not allowed to use weapons in such cases under Japan's unique 
standards, this is contrary to common sense and may be criticized by the international community. (p. 13)

The report also called for the addition of the "provision of protection" duty as follows: "[I]t is necessary to allow the SDF to use weapons $[\ldots]$ to remove obstructive attempts against its missions in accordance with UN PKO standards."

Gradually encouraged by the trends in the UNPKOs via the expert recommendations, the "provision of protection" and "coming-to-aid" duties were added in the 2015 amendments to the PKO Act. These amendments allowed the SDF peacekeepers to use weapons for the "execution of missions" purpose, which would go beyond self-preservation. In actuality, however, it remains highly questionable to what extent the addition of new tasks under the "execution of missions" purpose has reduced the gap in "robustness" between Japan and the general standard in the UNPKOs.

A gap emerged between the international standard on the use of weapons, as claimed by the panel, and the Japanese peculiar standard, as adopted by the 2015 amendment (Kurosaki, 2017). The difference originated from the discrepancy between the panel's recommendations and the stipulations in the 2015 amended PKO Act. First, the panel asserted that the "coming-to-aid" duty should be included as a "self-preservation" type because this understanding is commonly held in the UNPKOs. If categorized as a self-preservation type, the "coming-to-aid" duty would never constitute the use of force and would thus be exempt from the constraints regarding relations with state and quasi-state organizations. In reality, the Abe government categorized it as an "execution of the missions" type, and consequently, the requirement to avoid encounters with state and quasi-state organizations as adversary parties strictly restricted the JEG's leeway for performing "coming-to-aid" duties.

Second, and more essentially, the panel also demanded that the "use of weapons" for the UNPKOs not be equated with the "use of force," prohibited under Chapter 51 of the UN Charter. If this were the case, the peacekeepers' "use of weapons" would not violate the Constitution, even if categorized as an "execution of the mission" duty. The 2014 report (The Security Experts Panel, 2014) insisted as follows:

$[\mathrm{T}]$ here is no country that interprets the use of weapons recognized by the international standards of UNPKOs as use of force in international relations 
prohibited under the U.N. Charter. Therefore, the use of weapons by the SDF should be regarded as not constituting the use of force prohibited under Article 9 of the Constitution, even if the weapons are used for socalled "kaketsuke-keigo" [the "coming-to-aid" duty] or to remove obstructive attempts against its missions [the "execution of missions" duty] in accordance with relevant international standards, regardless of whether or not the attacker is a mere criminal group or "a state or "quasi-state organization."” (p. 38)

Despite the panel's strong demand, Prime Minister Abe flatly refused this recommendation because this was a very sensitive issue relating to the interpretation of Article 9 in the Constitution. On May 15, 2014, the same day when the Security Experts Panel's second report was released, Abe (2014) held a press conference and candidly declined the panel's recommendation as being incompatible with the GoJ's official standpoint.

Instead, the Abe administration adopted the unique Japanese interpretation, instead of the international standard view, that the "provision of protection" and "coming-to-aid" duties would constitute the use of force, if directed against a state or quasi-state organization as an adversary party (Kurosaki, 2017). Due to this unique interpretation, as stated above, the unique Japanese category of "execution of missions," which would cover both "provision of protection" and "coming-to-aid" duties, allowed only a much smaller range for the use of weapons for peacekeepers in comparison with the international standard of the "defense of the mandate."

Prime Minister Abe commented on the addition of the "coming-toaid" duty as follows: "[It] has made it possible for the SDF to come to the aid of Japanese nationals and NGOs in a manner that is pery close to the relevant international standards" (emphasis added) (Kurosaki, 2017, p. 200). The phrase "very close to the relevant international standards" implied that the "coming-to-aid" duty essentially differed from the international standards, excluding the use of weapons against a state or quasistate organization as an adversary party. Moreover, as seen earlier, the GoJ clearly differentiated Japan's peculiar category of the "execution of missions" from the international standard of the "defense of mandates."

Needless to say, the GoJ introduced these distinctions to eliminate the possibility of an unconstitutional use of force (Kishida, 2015a) because the anti-military camp was very critical of the use of weapons beyond the scope of "self-preservation," with serious concern about Japan's leaning toward "robustness" (Inoue, 2015). We can assume that closing the gap 
in "robustness" might not have been unimportant for Abe, but his top priority was to smoothly enact the entire Peace and Security Legislation while reducing the risk of inflaming the anti-military opposition. As a result of this compromise, which contradicted the Security Experts Panel's recommendations, the addition of new roles that went beyond selfpreservation reduced the "robustness" gap only to a limited extent.

In practice, meanwhile, it is very doubtful whether such a distinction can be made in the field. The recent UNPKOs are often operated in an uncertain with blurred boundaries, in which it might be extremely difficult to differentiate between state and non-state actors. Even though new duties were added beyond the scope of self-preservation, a considerable gap remained between the Japanese standard on the use of weapons under the "execution of missions" category, and the international standard of use of force for the defense of the mandate (see Chap. 1). This limit has generated practical difficulty for the GoJ in deploying the SDF for the "coming-to-aid" duty (as well as the "provision of protection" duty) and, presumably, developed in the troop withdrawal from South Sudan in 2017.

\section{Introducing the Other New Roles}

\subsection{The Joint Defense of a Camp}

The 2015 amendment to the PKO Act also relaxed the use of weapons under the "self-preservation" category: the joint defense of a camp. While deployed to a UNPKO, an SDF contingent often shares their camp with (a) fellow peacekeeping unit(s) contributed from other countries. Previously, the PKO Act did not allow the SDF personnel to actively protect an adjacent camp, even if it was under armed attack. The 2015 amendments to the PKO Act enabled the SDF to jointly protect camps under attack (Cabinet Secretariat, n.d.). The protection of a joint camp falls into the traditional category of self-preservation and the SDF personnel would be allowed to use weapons even against a state or quasi-state organization.

\subsection{The Internationally Coordinated Operations for Peace and Security and the Other Additions to the Amended PKO Act}

The original PKO Act envisaged three types of activities, namely UN peace operations, international humanitarian relief operations, and 
international supervision of elections (see Chap. 3). The 2015 amendments subsequently added a fourth category, namely "internationally coordinated operations for peace and security." These are operations that are similar to a UNPKO but take place outside the UN framework. To qualify as an internationally coordinated operation for peace and security, an operation needs approval in the form of a UNSCR or a UN Economic and Social Council resolution, or to receive a request from an international institution, such as one of the UN-related agencies (e.g., the UNHCR) or a regional organization (e.g., the European Union), or from concerned governments. This change was made in response to the recent increase in peace operations outside the UN framework. Under the new arrangement, Japan is now allowed to dispatch the SDF to support nonUN-affiliated operations; for example, military personnel have already been dispatched to a non-UN peace operation in the Sinai Peninsula since 2019 (see Chap. 9).

\subsection{Policies Related to SSR}

The amendment of the PKO Act in 2015 was also notable for introducing assistance to SSR: capacity-building support for fragile or conflict-affected states that specifically targets the reform and reconstruction of securityrelated institutions, ranging from armed forces, the police, and the judiciary to civilian oversight bodies, such as parliaments and bureaucracies. In recent years, SSR has attracted increasing attention in UN peace operations where establishing post-conflict security is by far the top priority.

Japan has little experience of working on SSR in the context of IPC, partly because there was formerly no provision for it in the PKO Act. However, Japan does have a record of similar support both within and outside the UNPKO framework, as demonstrated by its assistance with police reform in East Timor, through which it introduced community policing to the young nation (see Chap. 6). That said, Japan has so far been involved in only a limited number of cases, such as the East Timor example and also through bilateral arrangements with Indonesia, the Philippines, and elsewhere (National Police Agency, n.d.).

\subsection{Adopting the International Peace Support Act}

In the omnibus Peace and Security Legislation reform package, the International Peace Support Act was the only entirely newly enacted law. 
This is the "general law," or the "permanent law," for the overseas dispatch of the SDF (see Chap. 3), especially to join a non-UN multinational force with UNSCR authorization. In principle, the SDF could only be dispatched abroad under the PKO Act and the JDR Act. When dispatching the SDF abroad for other purposes, the GoJ had to enact a new law each time, as seen in the case of the Special Measures Law against Terrorism in 2001 and the Special Measures Law on Humanitarian and Reconstruction Assistance in Iraq in 2003 (see Chap. 3). Enacting a law, however, takes time, and this delay prevented Japan from responding to urgent calls to dispatch the SDF abroad. To overcome this problem, the GoJ had sought to adopt a general law, which was finally achieved by the International Peace Support Act. The new law now allowed the SDF to be dispatched in support of foreign military forces and other personnel in a non-UN multinational force whenever they are in "situation that the international community is collectively addressing for peace and security" (Mori, 2019, p. 7).

The International Peace Support Act allows the GoJ to participate in multinational forces outside of framework of UNPKOs without a new lawmaking each time. At the same time, however, the statute leaves many restrictions in place to avoid being involved in the use of force in a foreign country. Most critically, the new law requires prior consent from the Diet before the deployment of the SDF. This requirement would make it very difficult for the GoJ to deploy the SDF, even without the need for another new lawmaking. Even if not impossible, the stipulation would necessarily delay the deployment process. Moreover, although the new law permits the SDF to assist its allies only outside of the specific area in which combat actions are taking place and expects them to concentrate on rear-end support, such as logistics supply and transportation, it is still questionable whether it is realistic or feasible to maintain this distinction under volatile conditions.

\section{Summary of Chap. 4}

This chapter has examined how Japanese peacekeeping and related policies have recently changed under the second Abe administration, from 2013 to 2020. During this period, the GoJ largely caught up with the international peacekeeping trend of "robustness" in terms of the legal framework, such as the 2015 amendments to include the "provision of protection" and "coming-to-aid" duties in the PKO Act. Yet, in reality, it 
remains very difficult and politically risky for the GoJ to assign such expanded duties to SDF personnel. Therefore, the "robustness" gap between Japan and the rest of the international society remains considerable in practical terms. Meanwhile, the second Abe administration also paid careful attention to the international peacekeeping trend of "integration," prioritizing the "All Japan" approach above all. Reforms during the second Abe term expanded the leeway for Japan to dispatch its personnel to non-UN missions under the category of "internationally coordinated operations for peace and security" and with the new International Peace Support Act.

\section{Notes}

1. Previously, a relevant document, the Basic Policy on National Defense, was adopted in 1956, but it focuses more narrowly on defense issues.

2. The NDPG is the general policy framework for Japan's defense/security policy. Following its initial adoption in 1976, the NDPG was not updated until 1995. Since then, the NDPG has been revised every several years, accompanied by the revision of the Medium-Term Defense Capability Development Plan, which prescribes more details about the development and equipment of Japan's defense capability. The latest version, which is the ninth, was adopted in December 2019.

3. In 1992, the first ODA Policy Outline was adopted to articulate the basic principles in Japan's ODA Policy. After the second version was adopted in 2003, its scope was expanded as the Development Cooperation Policy Outline in 2015.

4. This section particularly relies on the specialist legal knowledge provided by Professor Katsuhiro Kurosaki of the National Defense Academy of Japan and Mr. Masayasu Tsuzuki of the University of Tokyo.

5. Officially, the GoJ translates the term nimmu-suiko as "defense of the mission mandate," but this expression could be confused with the UN term "the defense of the mandate." Hence, the book translates the term as "execution of the mandate."

6. When the former Japan Defense Agency was upgraded into a full ministry $(\mathrm{MoD})$ in 2007, the post of "Director-General of Defense" was also renamed as "Minister of Defense."

7. The principle of police proportionality would be applied to the use of weapons for the "execution of missions" duty: SDF personnel are allowed to use weapons only to the minimum extent (Kishida, 2015b).

8. The three types of UNPKO for the application of the new Five Principles, amended in 2015 (see Chap. 4), were inserted as a response to the request 
from the Komeito, the collation partner of ruling LDP. Characterized with the moderate anti-military inclination the Buddhist party tends to seek tighter regulations on the SDF's roles (see Chap. 2). Among the three types, the third item, the preventive deployment was hinted by the UN Preventive Deployment Force, deployed in Macedonia from 1995 to 1999. But this was only one existing case of preventive deployment as a part of UNPKOs and it seems very unlikely that another similar operation will be established in the future. According to the former government official, meanwhile, it could be theoretically possible to apply this type when the SDF is deployed for the emergency disaster relief purpose and if it may be succeeded to the deployment of UN peacekeepers, as it actually happed in Haiti in the 2010s (see Chap. 7; M. Tsuzuki, personal commutation, July 9, 2021).

9. Although military personnel (other than the SDF members themselves) are usually regarded as being outside the scope of the "coming-to-aid" duty, they may be protected if they lose the ability to protect themselves.

10. In the original texts of panel's report, it was written as "U.N. PKOs," but here we have written as the "UNPKOs" for the consistency of the terms throughout this book.

\section{REFERENCES (In ENGLish)}

Act on Cooperation with United Nations Peacekeeping Operations and Other Operations [The 2015 PKO Act], Act No. 79. (June 19, 1992, Amended on September 19, 2015).

Cabinet Secretariat. (2015, September 28). Statement by Prime Minister Shinzo Abe at the 2 nd leader's summit on peacekeeping. Prime Minister of Japan and His Cabinet. https://japan.kantei.go.jp/97_abe/statement/201509/1212997_ 9928.html

Kurosaki, M. (2017). The legal frameworks of coming-to-aid duty: The pluralism of the concept of self-defense and its multi-layered legal grounds. Japanese Yearbook of International Law, 60, 194-211.

MoFA. (2013, December 17). National security strategy. https://www.cas.go.jp/ jp/siryou/131217anzenhoshou/nss-e.pdf

MoFA. (2014, July 1). Cabinet decision on development of seamless security legislation to ensure Japan's survival and protect its people. https://www.mofa.go.jp/ $\mathrm{fp} / \mathrm{nsp} /$ page23e_000273.html

MoFA. (2015, February 10). Cabinet decision on the Development Cooperation Charter. https://www.mofa.go.jp/mofaj/gaiko/oda/files/000067701.pdf

MoFA. (n.d.). Japan's contribution. https://www.mofa.go.jp/policy/un/pko/ pdfs/contribution.pdf 
Mori, T. (2019). Decisions in Japan to use military force or participate in multinational peacekeeping operations. In C. A. Bradley (Ed.), The Oxford handbook of comparative foreign relations law. https://doi.org/10.1093/oxfordhb/ 9780190653330.013 .46

The Advisory Panel on Reconstruction of the Legal Basis for Security [The Security Experts Panel]. (2008, June 24). Report of the Advisory Panel on Reconstruction of the Legal Basis for Security. Prime Minister of Japan and His Cabinet. https:// www.kantei.go.jp/jp/singi/anzenhosyou/report.pdf

The Advisory Panel on Reconstruction of the Legal Basis for Security [The Security Experts Panel]. (2014, May 15). Report of the Advisory Panel on Reconstruction of the Legal Basis for Security. Prime Minister of Japan and His Cabinet. https:// www.kantei.go.jp/jp/singi/anzenhosyou2/dai7/houkoku_en.pdf

Uesugi, Y., Kobayashi, K., \& Honda, T. (2021). Japan's peacebuilding under the Abe administration: Change and continuity, 2012-2020. East Asian Policy, 13(01), 94-107.

\section{ReFERENCES (In JAPANESE)}

Abe, S. (2014, May 15). Abe-naikaku-sori-daizin kisha-kaiken [Press conference of Prime Minister Abe]. Prime Minister of Japan and His Cabinet. https:// warp.ndl.go.jp/info:ndljp/pid/8833367/www.kantei.go.jp/jp/96_abe/ statement $/ 2014 / 0515 \mathrm{kaiken} . \mathrm{html}$

Cabinet Secretariat. (n.d.). Jiei-tai no shin-nimmu "kaketsuke-keigo" oyobi "yaei-chi no kyodo-boei" [SDF's new mission tasks: The "coming-to-aid" duty and the “joint defense of a camp"]. Prime Minister's Office of Japan. Retrieved May 5, 2021, from https://www.kantei.go.jp/jp/headline/keigo.html

Cabinet Secretariat, Cabinet Office, MoFA, MoD. (2016). Shin-nimmu fuyo ni kansuru kihonteki-na kangae-kata [Basic guideline on SDF's new mission tasks]. https://www.kantei.go.jp/jp/headline/pdf/heiwa_anzen/kangaekata_20161115.pdf

GoJ. (1991, September 27). Seifu-teishutsu-shiryo "buki no shiyo to buryoku no koshi no kankei ni tsuite" [The GoJ's material on "the relations between the 'use of weapons' and the 'use of force"'].

Inoue, S. (2015, September 10). Dai-189-kai-kokkai, sangi-in, gaiko-boei-iin-kai, dai-25-go, [hatsugen-bango-124] [The $189^{\text {th }}$ Diet, House of Councilors, commission on foreign and defense affairs, (25), (statement No. 124)]. The $189^{\text {th }}$ Diet. https://kokkai.ndl.go.jp/\#/detail?minId=118913950X02520150910 \&spkNum $=124 \&$ single

Ishiba, S. (2003, June 4). Dai-156-kai-kokkai, sangi-in, buryoku-kogeki-jitai heno taisho ni kansuru tokubetsu-iin-kai, dai-11-go, [hatsugen-bango-194] [The $156^{\text {th }}$ Diet, House of Councilors, Special Committee on the Defense against 
Armed Aggression, (11), (statement No. 194)]. The $156^{\text {th }}$ Diet. https:// kokkai.ndl.go.jp/\#/detail? minId=1 15615053 X01 $120030604 \& s p k N u$ $\mathrm{m}=194$ \&single

Ishikawa, H. (2015, July 30). Dai-189-kai-kokkai, sangi-in, waga-kuni oyobi kokusai-shakai no heiwa-anzen-hosei ni kansuru tokubetsu-iin-kai, dai-5-go, [hatsugen-bango-191] [The 189 ${ }^{\text {th }}$ Diet, House of Councilors, special committee on the peace and security legislation for our nation and international society, (5), (statement No. 191)]. The $189^{\text {th }}$ Diet. https://kokkai.ndl.go.jp/\#/ detail? $\min I d=118913929$ X00520150730\&spkNum $=191 \&$ single

Kishida, F. (2015a, September 10). Dai-189-kai-kokkai, sangi-in, gaiko-boeiiin-kai, dai-25-go, [hatsugen-bango-125] [The 189 th Diet, House of Councilors, commission on foreign and defense affairs, (25), (statement No. 125)]. The $189^{\text {th }}$ Diet. https://kokkai.ndl.go.jp/\#/detail?minId=11891395 0X02520150910\&spkNum $=125 \&$ single

Kishida, F. (2015b, September 10). Dai-189-kai-kokkai, sangi-in, gaiko-boeiiin-kai, dai-25-go, [hatsugen-bango-127] [The 189 ${ }^{\text {th }}$ Diet, House of Councilors, commission on foreign and defense affairs, (25), (statement No. 127)]. The $189^{\text {th }}$ Diet. https://kokkai.ndl.go.jp/\#/detail?minId=11891395 0X02520150910\&spkNum $=125 \&$ single

Koizumi, J. (2002, February 5). Shugi-in-giin Kaneta Seiichi kun teishutsu "senso," "funso," "buryoku no koshi" to no chigai ni kansuru shitsumon ni taisuru tobensho [Clarification on the terminological differentiation of "wars," "conflicts," "the use of force" etc., submitted by Congressman Seiichi Kaneta]. The House of Representatives, Japan. https://www.shugiin.go.jp/internet/itdb_shitsumon.nsf/html/shitsumon/bl53027.htm

MoD. (2020). Boei-keikaku no taiko no gaiyo [Overview of Japan's defense concept]. Defense of Japan (Defense white paper), 215-220. https://www.mod. go.jp/j/publication/wp/wp2020/pdf/R02020302.pdf

MoD. (n.d.). Kempo to jiei-ken [The Constitution and the right of self-defense]. Ministry of Defense, Self-Defense Forces. Retrieved May 5, 2021, from https://www.mod.go.jp/j/approach/agenda/kihon02.html

MoFA. (2016, November 22). PKO-seisaku Q\&A [Q\&A on PKO policy]. https://www.mofa.go.jp/mofaj/gaiko/pko/q_a.html

Nakatani, G. (2015, September 10). Dai-189-kai-kokkai, sangi-in, gaikoboei-iin-kai, dai-25-go, [hatsugen-bango-119] [The 189 th Diet, House of Councilors, commission on foreign and defense affairs, (25), (statement No. 119)]. The $189^{\text {th }}$ Diet. https://kokkai.ndl.go.jp/\#/detail?minId=11891395 0X02520150910\&spkNum=119\&single

National Police Agency. (n.d.). Kokusai-kyoryoku no suishin [Promotion of international cooperation]. Retrieved July 7, 2021, from https://www.npa.go.jp/ bureau/soumu/kokusai/kyoryokujokyo.html 
Prime Minister of Japan and His Cabinet. (2002, December 18). Kokusaikyoryoku-kondan-kai-hokoku-sho no yoshi [The summary of report of the Experts Group on International Peace Cooperation]. https://www.kantei.go.jp/jp/ singi/kokusai/kettei/021218houkoku_s.html

The Central Committee of the Japanese Communist Party (JCP). (2015, September 20). Senso-hoan ni taisuru Koike-fuku-iin-cho no bantai-toron [Vicechairperson Koike's speech against the "war bills"]. The AKAHATA (on-line). https://www.jcp.or.jp/akahata/aik15/2015-09-20/2015092004_01_0.html

Yokobatake, Y. (2015, June 12). Dai-189-kai-kokkai, shugi-in, waga-kuni oyobi kokusai-shakai no heiwa-anzen-bosei ni kansuru tokubetsu-iin-kai, dai-9-go, [hatsugen-bango-18] [The 189 ${ }^{\text {th }}$ Diet, House of Representatives, special committee on the peace and security legislation for our nation and international society, (9), (statement No. 18)]. The $189^{\text {th }}$ Diet. https://kokkai.ndl.go.jp/ txt/118903929X00920150612/18

Open Access This chapter is licensed under the terms of the Creative Commons Attribution 4.0 International License (http://creativecommons.org/licenses/ by $/ 4.0 /$ ), which permits use, sharing, adaptation, distribution and reproduction in any medium or format, as long as you give appropriate credit to the original author(s) and the source, provide a link to the Creative Commons licence and indicate if changes were made.

The images or other third party material in this chapter are included in the chapter's Creative Commons licence, unless indicated otherwise in a credit line to the material. If material is not included in the chapter's Creative Commons licence and your intended use is not permitted by statutory regulation or exceeds the permitted use, you will need to obtain permission directly from the copyright holder.

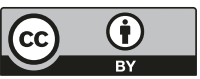

